\title{
REVIEW ON BIODEGRADABLE KITCHEN WASTE MANAGEMENT
}

\author{
Abira Mukherjee ${ }^{1}$, Goutam Kumar Bose ${ }^{2}$, Biswajit Mandal ${ }^{3}$, Avijit Ghosh ${ }^{4 *}$ \\ ${ }^{1}$ Assistant Professor, Mechanical Engineering Department, Haldia Institute of Technology, West Bengal, India \\ ${ }^{2}$ Professor, Mechanical Engineering Department, Haldia Institute of Technology, West Bengal, India \\ ${ }^{3}$ Assistant Professor, Chemical Engineering Department, Haldia Institute of Technology, West Bengal, India \\ ${ }^{4}$ Assistant Professor, Chemical Engineering Department, Haldia Institute of Technology, West Bengal, India \\ "Corresponding Author: Dr. Avijit Ghosh, Email: avijitghosh.che@gmail.com
}

\begin{abstract}
With the rapid urbanization managing of the kitchen waste generated by the large population has become a big problem. Kitchen wastes comprises of vegetables peels, fruit peels, smashed fibre of fruits, spare uneaten food items, food grains etc. These are loaded with nutrients and organic material, and can be easily recycled. In recent years, researchers have explored the various methods of extraction of biogases like Hydrogen, Methane, etc. from these biodegradable wastes. This paper reviews the various research works carried out on the synthesis of kitchen waste using anaerobic digestion process, biomethanation or composting. Hydrogen, a valuable gas is produced through the anaerobic fermentation of domestic organic waste in the absence of pretreatment or photo-fermentation, or bioaugmentation of indigenous fermentative communities. Chronological dark and photo fermentation process is also an emerging way studied for production of bio-hydrogen using kitchen waste. Esterification and hydrolysis process has also been utilized to synthesize kitchen waste forming Lactic acid. Thermo-chemical Hydrolysis of Kitchen Waste through optimization of temperature, time and chemical compositions, Fourier Transform Infrared Spectroscopy, microaeration process are studied resulting in bio-fuel production. Methane formation combining Kitchen Waste and black water using two-stage upflow anaerobic sludge blanket (UASB) septic tanks at the lower temperatures has also been studied and it appears to be more efficient than using only Black Water. Organic acids produced from anaerobic digestion of kitchen waste using an integrated method consisting of freezing, thawing, centrifugation, filtration and evaporation. Thus this review paper deals with the study of various methodologies of kitchen waste utilization.
\end{abstract}

Keywords: Anaerobic Digestion, Biomethanation, Composting, Esterification, Bioaugmentation, Centrifugation

\section{INTRODUCTION}

The production of solid waste has become a common problem worldwide. Solid wastes are the organic and inorganic waste materials formed through various forms in the society, which is losing their value to the users. Inappropriate dumping of these wastes pollutes the crucial components of the living environment like air, land and water globally. This problem has become more acute in developing nations like in India compared to developed nations. Solid waste is normally defined as unwanted solid, semi-solid material ensuing from human or animal activities. It is a diverse form of wastes, originating from industrial or agricultural, household, commercial activities. Solid waste comprises of Industrial Waste (IW), Hazardous Waste (HW), Municipal Solid Waste (MSW), Electronic waste (E-waste), Bio-Medical Waste (BMW) which depend on their supply \& characteristics. On one hand, the ecofriendly components of solid waste could be useful as secondary source for production processes. Some of the toxic and harmful ingredients cause a danger if not processed appropriately. Composting, Recycling, energy conversion from wastes, and land filling are some of the basic moves toward waste management $[1,2]$.

Urban Solid Waste popularly known as MSW(Municipal solid waste), is a type of waste that includes primarily household waste (domestic waste) in addition to construction ,destruction debris, commercial wastes, sanitation remains, waste collected by a municipality inside a given area. It can be found either in hard or semisolid form which generally excludes industrial hazardous wastes. MSW is broadly classified into broad categories as- ecological wastes like green waste, paper food and kitchen waste; recyclable resources like glass, paper, bottles, cans, metals, certain plastics, etc., and inert wastes like rocks, debris and dirt. Composite wastes include waste plastics such as toys, waste clothing; hazardous domestic waste and toxic waste like light bulbs, medicine, e-waste, fluorescent tubes paints, fertilizers, chemicals, spray cans, , pesticide containers, shoe polish ,batteries. Figure 1 represents the nomenclature of waste management. 


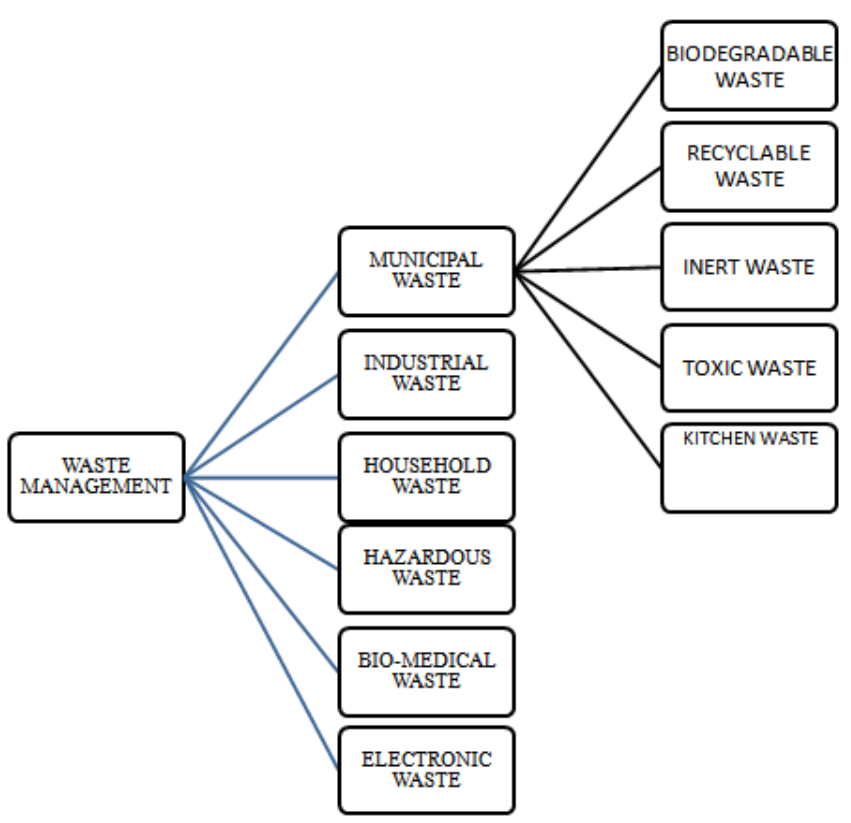

Fig-1: Nomenclature of waste management

\section{Kitchen Waste Management}

Kitchen wastes (KW) comprises of household kitchen wastes such as vegetables peels, fruit peels, smashed fibre of fruits, spare uneaten food items, food grains. $\mathrm{KW}$ is full of nutrients and organic materials, and simply biodegradable [3].

\subsection{Methods of Kitchen Waste Degradation}

Various methods for kitchen waste degradation has been adopted by various researchers like aerobic, anaerobic digestion, vermicomposting [4], etc which has been broadly discussed below.

\subsubsection{Aerobic Absorption Process}

Aerobic absorption process is an organic process which utilizes long-term aeration to counterpoise and decrease the total mass of organic waste by organically obliterating unstable solids. This process outspreads decomposition of solids and also re-growth of organisms up to a certain level where the energy obtained in living cells and waste material storage is considerably small.

During aerobic digestion, aerobic and facultative microorganisms employ oxygen and acquire energy from the existing biodegradable organic matter in the waste sludge. However, when the available food supply in the waste sludge is inadequate, the microorganisms start to feed on their own protoplasm to gain energy for own cell maintenance. This phenomenon is called endogenous respiration. The aerobic digestion process which occurs within in-vessel aerobic composters is identical to the process that takes place without human interference in environment.

In aerobic digestion, the end products are purely water, heat and $\left(\mathrm{CO}_{2}\right)$. As carbon dioxide is one of the greenhouse gases, and is at least $1 / 20^{\text {th }}$ as effective compared to methane, the influence of $\mathrm{CO}_{2}$ on the nature can be minimized by carefully collecting this $\mathrm{CO}_{2}$ gas using a gas collection arrangement which as a result will avert the gas from spreading out in the nature.

\subsubsection{Anaerobic Absorption Process}

Anaerobic absorption process is a micro-organic decomposition process of biological matter into carbon dioxide, methane, inorganic nutrients and compost in oxygen depleted region in the presence of the hydrogen gas [5]. Several anaerobes like Streptococcus, Clostridium, BacillusLactobacillus, Carnobacterium, Enterococcusand Homoacetogens, etc.have effect in the anaerobic fermentation process for organic waste [6,7]. This procedure is also well-known as bio-methanogenesis. Biogas being an end product is applied for combustion process in order to generate heat and electricity. It can also be developed into transportation fuels and renewable natural gas. The variety of anaerobic absorption technologies are transformed into municipal wastewater solids, livestock manure, high strength industrialized wastewater solids, fat, oils and grease (FOG), food waste, along with various other organic waste streams into organic-gas, $24 \times 7$ hours a week[8,9].Composting of separated digested solids help in dairy bedding, along with complete utilization of cropland or transformed into different products. Nutrients found in the liquid stream are utilized as fertilizers for agricultural purposes.

The break down procedure is initiated by bacterial hydrolysis as the main supplies in order to decompose to organic unsolvable polymers like carbohydrates, which is accessible for other bacteria. Then acidogenic bacteria transforms the amino acids and sugars into hydrogen, $\mathrm{CO}_{2}$, ammonia, and also other organic acids which then transform these decomposed organic acids in the form of acetic acid, and also decomposes to hydrogen, $\mathrm{CO}_{2}$, and ammonia. Finally, methanogens transforms these organic materials into $\mathrm{CO}_{2}$ andmethane gas. It can be utilized as an element of the procedure to treat sewage sludge and biodegradable wastes. Anaerobic absorption process diminishes the release of landfill gas into the atmosphere in case of integrated waste management method. It depends on various parameters like $\mathrm{pH}$ value [10], Composition of the Kitchen waste, OLR (organic Loading Rate), Retention time [11], and Operating Temperature. An efficient gain in process activity and time of the compost process can be achieved by a moderate control of the temperature at the primary low $\mathrm{pH}$ phase [12].

The production of Biogas from kitchen waste studied by the Malaysian Government has been investigated by the application of an anaerobic digester[13]. A study of the organic loading rate (OLR) and slurry concentration for maximum biogas production rate has been conducted which has resulted in a decrease in Consumed Oxygen Demand. Thus organic leftover is a supply that necessarily has to be stored and not to be disposed into landfills or burn to ashes and dust. 
Because of rapid growth of urbanization decomposing of KWM is a challenge. A laboratory size lot anaerobic coabsorption of all wastes with different mix ratio of $0: 100$, $25: 75,50: 50,75: 25$ and 100:0by volume [kitchen organic solid waste $(\mathrm{TS}=56,084 \mathrm{mg} / \mathrm{L})$ : sanitary wastewater $(\mathrm{TS}=$ $7,068 \mathrm{mg} / \mathrm{L})]$ are experimented at environmental temperature for 30 days [14]. The volume of methane and biogas generated during the digestion period for those mixing ratios are evaluated. The highest biogas obtained from a mix ratio of $75: 25$ was $65.6 \mathrm{~L}$, and the minimum from a mix ratio of $0: 100$ were $9.5 \mathrm{~L}$. The methane gas proportion in the biogas was amongst 19.8 and $52.8 \%$. From the outcomes obtained it is established that the mixing ratio of 75:25 produce the highest volume of methane and biogas.

Anaerobic treatment is used with a combination of black water and kitchen waste (BWKW) with dual-phased upflow anaerobic sludge blanket (UASB) septic reservoirs at low temperatures of 10 and $20^{\circ} \mathrm{C}$ [15]. As a result, the dualphased UASB-septic reservoirs proved effective along with capable of eliminating soluble as well as insoluble organic material from a mixture of black water and kitchen waste. As a result from black water alone methane gas was produced which decreased with decrease in temperature [16].Apart from the regular kitchen wastes, studies have been conducted on flower wastes and fresh vegetables collected from the market. Flower and vegetables are mixed at a ratio of $1: 4$ (wet weight) which is the ratio of $1: 1.3$ depending upon the dry weight [17]. Anaerobic Hydrolysis is accompanied in five different hydrolysis reactors which have a working volume of 1.4 Leach, which produces $\mathrm{CO}_{2}$ and $\mathrm{CH}_{4}$ gas. The results show that hydrolysis efficiency under anaerobic conditions is 1.4-2.4 times higher than cumulative TOC (Total Organic Compound) of the anaerobic batch.

\subsubsection{Vermicomposting and Fermentation}

Vermicomposting is an environmental friendly method of converting the organic portion of waste materials, in a cost effective manner and finally transforming it to a valueadded vermicompost [18]. By adding the vermicompost to the soil, less money would be spent on chemical fertilizers and pesticides[19]. Most of kitchen waste created from households and restaurants are rich in moisture content. Therefore composting and vermicomposting of kitchen wastes devoid of any bulking agent is very difficult to put into practice. Effect of pre-composted and raw kitchen waste with the addition of woodchips and paper in vermincomposting with regard to loss of weight, temperature, fluctuation of total and obtainable content of nutrients and feasibility of earthworms has been studied [20].Kitchen biowaste must be pre-composted for more than 2 weeks to reach a temperature below $25^{\circ} \mathrm{C}$. Vermicomposting increases the total content of $\mathrm{N}, \mathrm{P}, \mathrm{K}, \mathrm{Ca}$ along with $\mathrm{Mg}$ and checks the availability of $\mathrm{P}$ and $\mathrm{K}$. Earthworm usually feed on kitchen bio-waste like used paper that very often gets accumulated in an around the kitchen area. [21].
Urban solid waste in India mainly comprises of the $70 \%$ to $80 \%$ of domestic waste which are high in organic waste. A standard family produces up to $0.5-0.75 \mathrm{kgs}$ of kitchen waste per day. [22]. Environmental dilapidation under the present circumstances has further fortified due to the incessant production of $\mathrm{CO}_{2}$ and organic acids produced during microbial metabolism of vermin composting that eventually decrease the $\mathrm{pH}$ during the process. The potential of the composting process is found out by the amalgamation of the composting Palm oil mill sludge (PMOS) and solid waste (SW) in bin composter reactor. As a result, a noticeable dip in temperature along with declivity of moisture content and $\mathrm{PH}$ value is found during the process.

However, it is observed that co-decomposing Composting palm oil mill sludge (POMS) together with solid waste (SW) using a bin composter reactor has been used to find out the potential of the composting process [23].There was a fall in temperature, moisture content and $\mathrm{pH}$ value during the process. However, it is observed that co decomposing POMS with SW is the prime modus operandi followed for the alternative treatment to the disposal and recycling of the waste component.

Ligno-cellulolytic inoculants (EM bacteria and Trichoderma sp.) can also be used on scale of small to medium for composting of household waste by thermo-composting followed by vermin-composting which may or may not be accompanied by microbial inoculants. Therefore it can be said that ligno-celluloytic inoculants are not always necessarily important to accelerate the process of composting for onsite small scale household organic waste treatment.

A 3-L laboratory size hydrogen fermentor has been established by a feasibility study carried out by kitchen waste hydrogenation in semi-continuous process through fill-and-draw operation which is defined as intermittentcontinuous stirred tank reactor (I-CSTR) [24,25]. This includes four operational periods study. Organic wastes that are enriched in carbohydrates, KW residuals, can easily be converted into valuable products (i.e. lactic acid, bioethanol). On the other hand open fermentation has several advantages better than the conventional non fermented processes. This process helps to prevent Maillard reactions which reduce fermentable substrates, like sugars and amino acids.

Presence of sugar and amino acids in large amount enhances the production of furfural compounds, which curbs bacterial growth. Hydrolysis of a cellulosic material, (like KW), may accelerate the rate of succeeding enzymatic hydrolysis and enhance the generation of fermentable sugars from cellulose and hemicelluloses. However Ligno-cellulosic biomass, particularly difficult-to-degrade hemi-cellulosic sugars can be bio converted into value added compounds as well, besides the bio ethanol compound.

The recovery process of organic acids from fermented kitchen waste by the freezing and thawing method has been performed $[26,27]$. The total suspended solid patterns are 
observed during the fermentation. During the fermentation, the total suspended solids decreased gradually with time.

Various pretreatment methods to amplify or enhance the production of biomethane or its process have also been studied. The pretreatment methods were done before feeding of the reactors where the feed was stored for 2 weeks at below $4^{\circ} \mathrm{C}$ and raw kitchen waste was used without any dilution [28].

Among the various pre treatment methods to enhance the production of biomethane, the freeze-thaw treatment has opened avenues to give scope to interesting perspectives because it does not necessarily require the use of chemicals and further reduces the need for additional odor control.

Researchers have come up with an innovative approach for fermentative $\mathrm{H}_{2}$ production from common domestic organic waste in the absence of pretreatment. This approach is the self-fermentation of non-sterile vegetable waste and the bioaugmentation of microbial indigenous fermenting communities. The results of this approach are the three new $\mathrm{H}_{2}$-producing strains - Buttiauxella sp.4, Rahnella sp. 10 and Raoultella sp. 47. These three strains are individually tested on on two types of vegetable waste and eventually compared with a bacterial artificial group comprising of three strains [29].
In addition to the aforesaid approaches contributing to the various pre treatment methods, freshness preservation of kitchen waste, saccharification of the sugars in the waste, constant fermentation of ethanol in the saccharified liquid, and anaerobic treatment of the saccharification residue and the stillage to form ethanol using Saccharomyces cerevisiae yeast [30] has been duly performed.

In recent times, there is an identification drawn between hydrogen producing aerobic cultures such as Pseudomonos spp., Vibrio spp., Aeromonos spp and Anaerobic cultures such as Porphyromonos spp, Actinomyces spp., besides Clostridium spp. Acetic, Butaeric and Propaionic Acid are the cardinal products in hydrogen production that make judicial use of the anaerobic dark fermentation of carbohydrates.[31,32,33, 34].But methane is not produced as a byproduct since it is eliminated by heat digestion sludge $[35,36,37]$. A comparative study made in India between exotic and local group of earthworms meant for the calculating the efficiency during vermicomposting of solid waste. Two different species of worms, like L. mauritii, collected from soil in New Delhi, Indian Institute of Technology, the other species E. fetida were used [38]. Esterification and Hydrolysis Process has been used also to produce Lactic Acid by fermentation [39].

The table 1 shown below is a comparative study of some of the works related to kitchen waste management.

Table 1: Comparative Study on KWM

\begin{tabular}{llll}
\hline Organisms & Products & Methods & References \\
\hline $\begin{array}{l}\text { Buttiauxella sp.4, Rahnella sp. 10 and } \\
\text { Raoultella sp. 47 }\end{array}$ & Hydrogen & Bio-augmentation and Self fermentation & [27]
\end{tabular}

\begin{tabular}{|c|c|c|c|}
\hline $\begin{array}{l}\text { Epigeic species (Eiseniafetida) and an } \\
\text { anecic species Lampitomauritii) }\end{array}$ & $\begin{array}{l}\text { Nitrogen, Phosphorus, } \\
\text { Potassium }\end{array}$ & Vermicompos-ting & [25] \\
\hline Aspergillus niger C-5 & $\begin{array}{l}\text { Fungal Cellulase } \\
\text { System }\end{array}$ & Solid state fermentation & [37] \\
\hline- & $\begin{array}{l}\text { Methane and other } \\
\text { bio-gas }\end{array}$ & Controlled Temperature & [13] \\
\hline Lactobacillus acidophilus & Lactic Acid & Fermentation & [27] \\
\hline Saccharomyces cerevisiae $\mathrm{KF}-7$ & Ethanol & Anaerobic Treatment & \\
\hline $\begin{array}{l}\text { Clostridium stercorarium } \\
\text { Clostridium thermolacticum } \\
\text { Clostridium aldrichii } \\
\text { Clostridium cellobioparum } \\
\text { Clostridium termitidis }\end{array}$ & Hydrogen & $\begin{array}{l}\text { Anaerobic Hydrogen Fermentation using } \\
\text { Fill and Draw Operation }\end{array}$ & [26] \\
\hline
\end{tabular}

\section{PRESENT SCENARIO}

In modern researches Biodegradable Kitchen waste has been used as a substrate and optimized to produce Fungal Cellulase System by different Statistical Modelling Methods like Plackett-Burman designs [40]. A fungal strain of Aspergillus niger C-5.is used by the process of solid state fermentation to yield low cost cellulose system [41]. Biowaste(mixture of yard waste and kitchen waste) has been decomposed and studied using Fourier transform infrared (FTIR) spectroscopy and pyrolysis-field ionization mass spectrometry (Py-FIMS)[42]. Py-FIMS method helps to separate and identify different chemical compounds in a sample after thermal degradation and ionization [43].

\section{CONCLUSIONS}

The present studies suggest a comparative study of different approaches taken so far for kitchen waste management. Here different degradation techniques are highlighted where the parameters are controlled effectively in order to have a useful byproduct. 
The major challenges in bio-gas, $\mathrm{H}_{2}$, organic acids etc. produced from wastes are their low yield rates. Large volumes of reactors are needed for producing them to overcome their low production rates. By selecting and applying more competent organisms, finding more proficient processing methods, optimizing the ecological conditions and stringent control of experimental parameters leads to improved yields and production rates.

\section{REFERENCES}

[1] Pande L., Nagarnaik P.B., Conversion of Biodegradable Waste to Fertilizer and Energy, International Journal of Advanced Engineering Sciences and Technology, 2011, Vol No. 5, 2:277-281.

[2] Veeken A., Hamelers B., Effect of temperature on hydrolysis rates of selected biowaste components, Bioresource Technology1999, 69: 249-254.

[3] Soliva M. L. M., Martínez-Farré F. X., Fernández M., Pujol O. H., Evaluation of MSW organic fraction for composting: Separate collection or mechanical sorting Resources, Conservation and Recycling, 2010, 54: 222228.

[4] Illmer P., Gstraunthaler G. , Effect of seasonal changes in quantities of biowaste on full scale anaerobic digester performance, Waste Management,2009, 29:162-167.

[5] UenoY., Sasaki D., Fukui H., Haruta S., Ishii M., Igarashi Y., Changes in bacterial community during fermentative hydrogen and acid production from organic waste by thermophilic anaerobic microflora, Journal of Applied Microbiology, 2006,101:331-343.

[6] Arsova L., Anaerobic digestion of food waste: Current status, problems and an alternative product, MS Thesis,Fu Foundation of Engineering and Applied Science Columbia University, 2010.

[7] Garg S.K., Sewage Disposal and Air Pollution Engineering, Khanna Publishers, 2011.

[8] Green J.H., Kramer A., Food Processing Waste Management; AVI, 1979.

[9] Liu, Fang C., Yuan, Zhong X., Zeng, Ming G. , Li Wei W., Jing L., Prediction of methane yield at optimum $\mathrm{pH}$ for anaerobic digestion of organic fraction of municipal solid waste, Bioresource Technology, 2007,99:882888.

[10] Viswanath, P., Sumithra Devi, S. \& Nand, K., Anaerobic Digestion of Fruit and Vegetable Processing Wastes for Biogas Production, Bioresource Technology, 1991,40:43- 48

[11] Malakahmad A. , Basri N.E.A , Md Zain S.,Production of Renewable Energy by Transformation of Kitchen Waste to Biogas, Case Study of Malaysia, ISBEIA,2011.

[12] Smars S., Gustafsson L., Beck-Friis B., Jonsson H., Improvement of the composting time for household waste during an initial low $\mathrm{pH}$ phase by mesophilic temperature control, Bioresource Technology, 2002, 84: 237-241.

[13] Minale M., Worku T., Anaerobic co-digestion of sanitary wastewater and kitchen solid waste for biogas and fertilizer production under ambient temperature: waste generated from condominium house, Int. J.
Environ. Sci. Technol., 2014, 11:509-516.

[14] Luostarinen S., Rintala J., Anaerobic on-site treatment of kitchen waste in combination with black water in UASB-septic tanks at low temperatures, Bioresource Technology, 2007, 98:1734-1740.

[15]Zeeman, G., Lettinga, G., The role of anaerobic digestion of domestic sewage in closing water and nutrient cycle at community level. Water Sci. Technol, 1999, 39:187-194.

[16]Zhu M., Hao F.L.L, He P., Shao L.M, Regulating the hydrolysis of organic wastes by micro-aeration and effluent recirculation, Waste Management, 2009, 29: 2042-2050.

[17] Sherman R.L., Vermi-composting for businesses and institutions. In: Edwards CA, Arancon N, Sherman R (eds) Vermiculture technology, 2011, 391-408.

[18] Sinha R.K., Agarwal S., Chauhan K., Valani D., The wonders of earthworms \& its vermicompost in farm production: Charles Darwin's friends of farmers, with potential to replace destructive chemical fertilizers from agriculture. Agric Sci, 2010, 1:76-94.

[19] Vavouraki A.I, Angelis E.M, Kornaros M., Optimization of thermo-chemical hydrolysis of kitchen wastes, Waste Management, 2013, 33:740-745.

[20]Hanc A., Pliva P., Vermicomposting technology as a tool for nutrient recovery from kitchen bio-waste, J Mater Cycles Waste Management,2013,15:431-439.

[21] Chaudhuri S., Pal T.K, Bhattacharjee G. , Dey S.K., Chemical changes during vermicomposting (Perionyx excavatus) of kitchen wastes, Tropical Ecology, 2000, 41:107-110.

[22] Tweib S.A.K. , Rahman R.A. ,Khalil M.S., Physicochemical Changes in Composting Process of Palm Oil Mill Sludge (POMS) and Solid Waste (Kitchen Waste) Using Bin Composter, Arab Journal Science Engineering, 2014, 39:2455-2462.

[23] Nair J., Okamitsu K.,Microbial inoculants for small scale composting of putrescible kitchen wastes, Waste Management, 2010, 30:977-982.

[24] Omar F.N, Rahman A., Hafid H.S., Yee P.L.,Hassan M.A., Separation and recovery of organic acids from fermented kitchen waste by an integrated process, African Journal of Biotechnology Vol. 8 , 2008,21: 5807-5813.

[25] Tripathi G., Bhardwaj P., Decomposition of kitchen waste amended with cow manure using an epigeic species (Eisenia fetida) and an anecic species (Lampito mauritii),2004,Bioresource Technology ,92,215-218.

[26] Li S.H., Kuo S.C., Lin J.S., Lee Z.K., Wang Y.H., Cheng S.S., Process performance evaluation of intermittent-continuous stirred tank reactor for anaerobic hydrogen fermentation with kitchen waste, International Journal of Hydrogen Energy, 2008, 33:1522-1531.

[27] Probst M., Walde J., Pümpel T.,Wagner A.O., Insama H., A closed loop for municipal organic solid waste by lactic acid Fermentation,BioresourceTechnology,2015,175: 142 151

[28] Maa J., Duong T.H. , Smits M., Verstraete W., Carballa M., Enhanced biomethanation of kitchen waste by 
different pre-treatments, Bioresource Technology, 2011, 102:592-599.

[29] Marone A., Massini G., Patriarca C., Signorini A., Varrone C., Izzo G., Hydrogen production from vegetable waste by bioaugmentation of indigenous fermentative communities, International Journal of Hydrogen Energy,2012, 37:5612-5622.

[30] Tang Y.Q, Koike Y., Liu K., An M.Z, Morimura S., Wu X.L, Kida K., (2008), Ethanol production from kitchen waste using the flocculating yeast Saccharomyces cerevisiae strain KF-7, Biomass and Bioenergy, 2008, 32:1037-1045.

[31] Kapdan I.K., Kargi F., Review Bio-hydrogen production from waste materials, Enzyme and Microbial Technology,2006, 38: 569-582

[32] Collet C., Adler N., Schwitzgu'ebel J.P., P'eringer P., Hydrogen production by Clostridium thermolacticum during continuous fermentation of lactose, Int $\mathbf{J}$ Hydrogen Energy, 2004, 29:1479-85.

[33] Tanisho S., Ishiwata Y., Continuous hydrogen production from molasses by bacterium Enterobacter aerogenes, Int J Hydrogen Energy, 1994, 19:807-12.

[34] Tanisho S., Ishiwata Y., Continuous hydrogen production from molasses by fermentation using urethane foam as a support of flocks, Int $\mathbf{J}$ Hydrogen Energy, 1995, 20: 541-544.

[35] Liu G., Shen J., Effects of culture medium and medium conditions on hydrogen production from starch using anaerobic bacteria, J Biosci Bioeng, 2004, 98: 251-256.

[36]Lin C.Y., Lay C.H., Carbon/nitrogen ratio effect on fermentative hydrogen production by mixed microflora, Int J Hydrogen Energy, 2004, 29: 41-45.

[37] Yu H., Zhu Z., Hu W., Zhang H., Hydrogen production from rice winery wastewater in an uplow anaerobic reactor by mixed anaerobic cultures, Int $\mathbf{J}$ Hydrogen Energy, 2002,27:1359-65.

[38] Kaviraj, Sharma S., Municipal solid waste management through vermicomposting employing exotic and local species of earthworms. Bioresource Technology, 2003, 90: 169-173

[39]Zhaoa W. , Wanga X.S.Q. Maa H., Tenga Y. , Lactic acid recovery from fermentation broth of kitchen garbage by esterification and hydrolysis method, Biomass and Bioenergy,2009, 33: 21- 25

[40] Janveja C., Rana S.S., Soni S.K., Waste Biomass Valor, 2014, 5: 807-821.

[41] Amani M.D., Ahwany A.S., Xylanase production by Bacillus pumilus. Optimization by statistical and immobilization methods, Res. J. Agric. Biol. Sci., 2007, 3:727-732.

[42] Smidt E., Eckhardt K.U., Lechner P., Schulten H.R., Leinweber P., Characterization of different decomposition stages of biowaste using FT-IR spectroscopy and pyrolysis-field ionization mass spectrometry, Springer Biodegradation, 2005, 16: 6779.

[43]Leinweber P., Schulten H.R., Advances in analytical pyrolysis of soil organic matter. J. Anal. Appl. Pyrolysis, 1998, 47:165-189.

\section{BIOGRAPHIES}

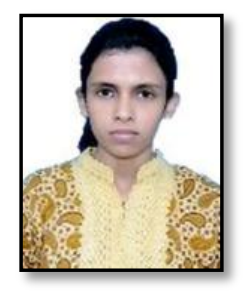

Ms. Abira Mukherjee, Assistant Professor, Mechanical Engineering Department, Haldia Institute of Technology, Haldia-721657

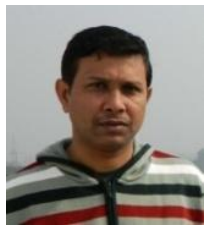

Dr. Goutam Kumar Bose, Professor in Mechanical Engineering Department, Haldia Institute of Technology, Haldia, India. He has obtained Ph.D from, Jadavpur University, Kolkata. His active areas of interests are Metal Cutting, Nonconventional machining, Industrial and Production Management and optimization techniques.

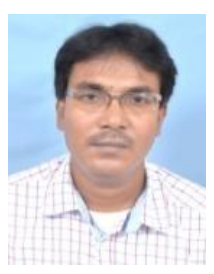

Mr. Biswajit Mandal, Assistant Professor, Haldia Institute of Technology, Haldia. His research interest on hydrogen energy, electrolysis.

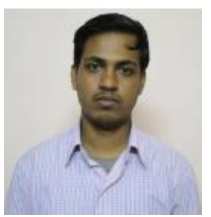

Dr. Avijit Ghosh, received his $\mathrm{PhD}$ degree from IIT Guwahati and M.Tech from Calcutta University. His research interest in the energy conversion device, graphene synthesis and its application, fuel cell. He has published 6 international peer review journal and 16 national and international conferences proceedings. 